\author{
논에서 배수조건에 따른 사일리지용 옥수수 품종의 생육특성, \\ 생산성 및 품질 비교 \\ 지희정 · 김원호 · 김기용 · 이상훈 · 윤세형 · 임영철
}

\title{
Effect of Different Drained Conditions on Growth, Forage Production and Quality of Silage Corn at Paddy Field
}

Hee Chung Ji, Won Ho Kim, Ki Yong Kim, Sang-Hoon Lee, Sei Hyung Yoon

\author{
and Young Chul Lim
}

\begin{abstract}
This experiment was carried out to know adaptability and forage production and quality of corn hybrid for silage at paddy field from 2007 to 2008 at Chungnam province. Growth, forage production and quality of silage corn showed more well drained condition than poorly drained condition at paddy field. Among growth characteristics, 'Kwangpyongok' and 'DK697' hybrids were somewhat strong for waterlogging, then and good at stay green, lodging, disease and insect resistance. Fresh yield of 'DK697' hybrid at poorly drained paddy field was the highest as $32,610 \mathrm{~kg}$ per ha among corn hybrids. The dry yield of 'P32P75' hybrid at poorly drained paddy field was the highest as $14,910 \mathrm{~kg}$ per ha The result of this study showed that 'P32P75', 'DK697', 'Kangdaok' and 'Kwangpyongok' hybrids had good growth characters and forage productivity at poorly drained paddy field and dry matter yield at poorly drained paddy field was $65.6 \%$ level compared with well drained paddy field.
\end{abstract}

(Key words: Silage corn, Yield, Dry matter, TDN, Forage)

$$
\text { I. 서 론 }
$$

최근 유가 상승으로 인한 해상운임과 조사료 수입 가격은 매년 상승하고 있으며 국내 조사 료 시장 중에서 양질 조사료가 차지하는 비중 은 $32 \%$ 에 불과하여 축산농가의 대부분은 볏짚 을 이용하여 가축을 사양하고 있는 실정이다. 따라서 안정적인 양질 조사료 생산 기반 시설 을 확충하기 위해서는 겨울철에는 답리작으로 이탈리안 라이그라스, 청보리 등을 재배하고
여름철에는 옥수수, 수수 $\times$ 수단그라스 교잡종 등의 재배면적 확대가 절실히 필요하다. 그러 나 밭은 대부분 고소득 작물의 재배로 여름철 사료작물을 재배할 밭의 면적은 제한적이기 때 문에 앞으로는 밭보다 논이나 간척지 및 휴경 지 등에서 조사료를 생산할 수 있는 연구가 필 요하다고 판단된다. 또한 국내 식품 소비패턴 이 과거와는 상당히 변화하여 쌀의 국내 소비 가 연간 1 인당 1998 년 $99.2 \mathrm{~kg}$ 에서 2008 년에 $75.8 \mathrm{~kg}$ 로 $74.4 \%$ 로 감소된 반면 육류식품의 소

국립축산과학원 (National Institute of Animal Science, RDA, Cheonan, 330-801, Korea)

Corresponding author: Ph. D. Hee Chung Ji, National Institute of Animal Science, Cheonan 330-801, Korea.

Tel: +82-41-580-6749, Fax: +82-41-580-6779, E-mail: cornhc@korea.kr 
비가 증가되고 있다(통계청, 2009). 이는 벼 재 배 면적의 감소로 이어져 많은 유휴지가 발생 될 가능성이 높다고 할 수 있다.

여름철 대표적인 사료작물인 옥수수를 논에 재배할 경우 단위면적당 조사료 생산성이 높아 양질의 조사료 확보에 유리하고, 농후사료의 원료인 종실 생산도 가능하기 때문에 국내 사 료 자급률 향상과 외화절약을 꾀할 수 있는 일 석이조의 효과를 거둘 수 있다.

옥수수를 논에 재배할 때에 가장 큰 문제점 은 옥수수가 다른 작물에 비해 습해에 약하고 논의 특성상 장마철에 배수가 잘 안되기 때문 에 논에 물이 오랫동안 고여서 습해가 발생될 우려가 있다. 하지만 옥수수는 전 생육기간에 많은 수분을 필요로 하기 때문에 밭 보다는 논 에서 어느 정도의 배수만 이루어진다면 재배가 가능하다고 할 수 있다. 또한 지속적인 수분 보유로 옥수수 생육에 유리하고 다른 한편으로 는 밭보다는 잡초의 발생이 적어 사일리지의 품질이 좋고 관리가 용이하다고 할 수 있는데, 일반적으로 옥수수를 재배할 논토양의 경우 수 직배수가 잘되는 사질 점질토가 가장 유리하고 수직배수가 안되는 토양은 수평배수가 잘되는 토양조건 즉 물이 잘 흘러내리는 논토양에서 옥수수 재배가 가능하다고 할 수 있다.

일반적으로 밭토양에서 사일리지용 옥수수에 대한 연구는 많으나(김 등 1992; 김 등 1998; 김 등 1999 ; 최 등 2008), 논에서 재배하는 사 일리지용 옥수수에 대한 연구는 많지 않다(이 등, 1986; 이 등, 1994; 박 및 김, 2002; 지 등, 2006). 그러나 최근에 논 재배 사료용 옥수수에 대한 생육특성 및 생산성 연구는 지 등 (2009) 에 의해 보고된 바 있다. 그러나 배수조건에 따른 논 재배 사일리지용 옥수수에 대한 연구 는 미흡한 실정이다. 따라서 본 연구는 논에 여름철 사료작물인 옥수수를 재배하는데 있어 서 배수가 양호한 논과 불량한 논 등 배수조건
에 따른 옥수수의 생육특성과 수량성을 비교하 여 논 재배 사일리지용 옥수수의 기초자료로 활용코자 실시하였다.

\section{ㅍ. 재료 및 방법}

공시재료는 국내 육성 보급종인 광평옥과 강 다옥 등 2품종과 도입품종인 P3394, P3156, $\mathrm{P} 32 \mathrm{P} 75, \mathrm{DK} 697$ 등 4품종 총 6품종이었다. 파 종은 1 년차에 충청남도 아산과 천안 농가포장 에 2007년 5월 1일, 2년차에는 2008년 4월 21 일에 실시하였다. 시험구 배치는 난괴법 3반복 으로 하였고 재식거리는 $70 \times 15 \mathrm{~cm}$ 로 시험구당 $12 \mathrm{~m}^{2}$ 로 하여 주당 2립 파종후에 4 5엽기에 1 주만 남겨두고 솎아주었다. 시비량은 ha당 질 소 $(\mathrm{N}) 200 \mathrm{~kg}$, 인산 $\left(\mathrm{P}_{2} \mathrm{O}_{5}\right) 150 \mathrm{~kg}$, 그리고 칼리 $\left(\mathrm{K}_{2} \mathrm{O}\right) 150 \mathrm{~kg}$ 로 하였으며, 그 중에서 질소비료 는 절반을 기비로 시용하였고 7 8 엽기에 나 머지 절반을 주었다. 또한 인산이나 칼리비료 는 기비로 전량 시비하였다. 기타 비배관리는 농촌진흥청 옥수수 표준재배법에 따랐다. 생육 조사는 간장, 착수고, 경직경, 출사기, 당도, 내 습성, 병해, 충해 등을 조사하였다. 당도는 휴 대용 굴절당도계 (일본)로 측정하였고 내습성정 도는 9등급 $[1$ (강) 9(약)]으로 나누어 달관조사 하였다. 수량은 구당 4 열 가운데 중앙에 2 열을 예취하여 측정하였고 건물중은 이들 중의 일부 샘풀을 취하여 건조기에 $65^{\circ} \mathrm{C}$ 에서 7 일간 건조 한 후 건물중을 측정하여 계산하였다. 그리고 건물수량은 생초수량에 건물률을 곱하여 환산 하였고, TDN 수량은 Pioneer Hi-Bred사가 제시 한 공식 $\mathrm{TDN}$ 건물수량 $=($ 경엽 건물수량 $\times$ $0.582)+($ 암이삭 건물수량 $\times 0.85)$ 에 의하여 계 산하였다(Holland 등, 1990). 그 중 일부를 취 하여 20 mesh screen의 Wiley mill로 분쇄하여 플라스틱 용기에 이중마개로 막아 분석시까지 보관하였으며 시료의 일반성분은 $\mathrm{AOAC}$ 법 
Table 1. Chemical properties of paddy field in this experiment

\begin{tabular}{cccccccccc}
\hline \multirow{2}{*}{$\begin{array}{c}\text { Paddy } \\
\text { field }\end{array}$} & $\mathrm{pH}$ & \multirow{2}{*}{$\begin{array}{c}\mathrm{T}-\mathrm{N} \\
(\%)\end{array}$} & $\begin{array}{c}\mathrm{P}_{2} \mathrm{O}_{5} \\
(\mathrm{mg} / \mathrm{kg})\end{array}$ & $\begin{array}{c}\mathrm{OM} \\
(\mathrm{g} / \mathrm{kg})\end{array}$ & $\begin{array}{c}\mathrm{CEC} \\
(\mathrm{cmol} / \mathrm{kg})\end{array}$ & $\mathrm{K}$ & $\mathrm{Na}$ & $\mathrm{Ca}$ & $\mathrm{Mg}$ \\
\hline \hline PDPF* $^{*}$ & 5.78 & 0.17 & 104.52 & 10.42 & 13.31 & 1.69 & 0.71 & 3.90 & 14.56 \\
WDPF $^{*}$ & 6.10 & 0.22 & 102.42 & 14.96 & 14.46 & 1.33 & 0.68 & 6.14 & 2.11 \\
\hline
\end{tabular}

WDPF : well drained paddy field, PDPF : poorly drained paddy field.

(1990)으로 분석하였으며, $\mathrm{ADF}$ (acid detergent fiber)와 NDF (neutral detergent fiber)는 Goering 과 Van Soest (1970)의 방법으로 분석하였다. 논 시험 포장의 토양조건을 조사한 결과는 Table 1과 같다.

배수가 불량한 논토양의 산도 $(\mathrm{pH})$ 는 5.78 로 옥수수 재배의 적정범위인 6.0 -6.5 보다 약간 낮았으며 배수가 양호한 논은 6.1로 적정범위 였고, 유기물 함량은 적정범위인 $20 \sim 30 \mathrm{~g} / \mathrm{kg}$ 보다는 배수가 불량 논에서 $10.42 \mathrm{~g} / \mathrm{kg}$ 로, 배수 가 양호한 논에서는 $14.96 \mathrm{~g} / \mathrm{kg}$ 으로 대체로 낮 았다. 인산 함량은 적정범위인 $150 \sim 250 \mathrm{mg} / \mathrm{kg}$ 에 비해 배수가 불량한 논과 양호한 논에서 부 족하였다. 치환성 양이온에서는 마그네슘 함량 의 적정범위 $(1.5 \sim 2.5)$ 에 비해 배수가 불량 논 에서 $14.56 \mathrm{cmol} / \mathrm{kg}$ 로 상당히 높았고 배수가 양 호한 논에서는 $2.11 \mathrm{cmol} / \mathrm{kg}$ 으로 적정범위이었 다 (농진청, 2006).

\section{III. 결과 및 고찰}

\section{1. 사일리지용 옥수수의 생육특성}

배수조건이 다른 논에서 사일리지용 옥수수 를 재배한 결과 그들 품종들의 생육특성에 대 한 결과는 Table 2 와 Table 3 과 같다. 국내육성 품종인 광평옥은 Table 2에서와 같이 출사일수 는 배수가 양호한 논토양에서는 85 일, 불량토 양에서는 83 일로 배수가 불량토양에서 2 일 빨
랐으나 강다옥은 배수가 불량한 논에서 오히려 1일 더 걸렸고 $\mathrm{P} 3156$ 은 2일, DK697은 4일간 차이가 발생하였다. 그러나 통계적인 유의성은 인정되지 않았다.

간장은 배수가 불량한 논이 배수 양호한 논 에 비해 평균 $83 \mathrm{~cm}$ 가 작아져 $31.4 \%$ 가 감소하 였는데, 배수가 양호한 논에서는 P32P75가 278 $\mathrm{cm}$ 로, 배수가 불량한 논에서는 광평옥이 200 $\mathrm{cm}$ 로 가장 길었고 간장의 감소폭이 가장 큰 품종은 $\mathrm{P} 32 \mathrm{P} 75$ 로 $98 \mathrm{~cm}$ 가 작아졌고 가장 영향 을 덜 받은 품종은 국내품종 중에서는 광평옥, 도입품종 중에서는 P3394로 $75 \mathrm{~cm}$ 가 작아졌는 데 그 범위는 75 98 cm였다. 이와 같은 이유 로 논에 옥수수를 재배 할때는 배수가 양호한 입지조건을 선정하여 재배하여야 바람직할 것 으로 판단된다.

Aldrich 등 (1986)과 김 등 (1997)은 간장이 길 고 착수고가 높은 품종이 도복이 증가하고 이 는 수량감소를 유발한다고 보고하였는데, 도복 에 영향을 주는 착수고는 배수가 불량한 논토 양이 배수 양호한 논토양에 비해 평균 $56 \mathrm{~cm}$ 가량 낮아 감소율은 $58.5 \%$ 로 컸는데, 감소 이 유는 간장이 작아졌기 때문이라 사료된다. 시 험품종 중에서 배수 양호한 논재배와 비교하여 배수가 불량한 논에서 착수고 감소가 가장 작 은 품종은 DK697과 P3394로 각각 $47 \mathrm{~cm}, 51$ $\mathrm{cm}$ 등이었고 착수고 감소가 가장 큰 품종은 강다옥, $\mathrm{P} 32 \mathrm{P} 75$ 등 이었다. 이상과 같은 결과 로 살펴보면 간장이나 착수고는 수량 구성요소 
Table 2. Agronomic characters of corn hybrids for silage at paddy field on different drained conditions

\begin{tabular}{|c|c|c|c|c|c|c|}
\hline \multirow[b]{2}{*}{ Hybrids } & \multicolumn{2}{|c|}{ Days to silking } & \multicolumn{2}{|c|}{ Stem height $(\mathrm{cm})$} & \multicolumn{2}{|c|}{ Ear height $(\mathrm{cm})$} \\
\hline & $\begin{array}{l}\text { WDPF } \\
\text { (A) }\end{array}$ & $\begin{array}{c}\text { PDPF } \\
\text { (B) }\end{array}$ & $\begin{array}{l}\text { WDPF } \\
\text { (A) }\end{array}$ & $\begin{array}{c}\text { PDPF } \\
\text { (B) }\end{array}$ & $\begin{array}{c}\text { WDPF } \\
\text { (A) }\end{array}$ & $\begin{array}{c}\text { PDPF } \\
\text { (B) }\end{array}$ \\
\hline Kwangpyongok & $85 \mathrm{a}$ & $83 a$ & $275 \mathrm{ab}$ & $200 \mathrm{a}$ & $137 \mathrm{a}$ & $82 \mathrm{a}$ \\
\hline Kangdaok & $88 \mathrm{a}$ & $89 a$ & $270 \mathrm{ab}$ & $178 b$ & $144 \mathrm{a}$ & $79 \mathrm{a}$ \\
\hline P3394 & $84 a$ & $83 a$ & $247 b$ & $172 b$ & $121 \mathrm{a}$ & $70 \mathrm{a}$ \\
\hline P3156 & $88 \mathrm{a}$ & $91 \mathrm{a}$ & $266 a b$ & $180 \mathrm{~b}$ & $133 a$ & $80 \mathrm{a}$ \\
\hline P32P75 & $84 a$ & $84 a$ & $278 \mathrm{a}$ & $180 \mathrm{~b}$ & $140 \mathrm{a}$ & $75 \mathrm{a}$ \\
\hline DK697 & $87 \mathrm{a}$ & $91 \mathrm{a}$ & $258 \mathrm{ab}$ & $190 \mathrm{ab}$ & $133 \mathrm{a}$ & $86 a$ \\
\hline Mean & 86 & 87 & 266 & 183 & 135 & 79 \\
\hline $\mathrm{B} / \mathrm{A}(\%)$ & \multicolumn{2}{|c|}{101} & \multicolumn{2}{|c|}{68.6} & \multicolumn{2}{|c|}{58.5} \\
\hline
\end{tabular}

WDPF(A): well drained paddy field, PDPF(B): poorly drained paddy field.

* Means within a column followed by the same letter are not significantly different at the $5 \%$ level by Duncan's multiple range test.

Table 3. Continued

\begin{tabular}{|c|c|c|c|c|c|c|}
\hline \multirow[b]{2}{*}{ Hybrids } & \multicolumn{2}{|c|}{ Stem diameter $(\mathrm{mm})$} & \multicolumn{2}{|c|}{ Waterlogging $(1 \sim 9)^{*}$} & \multicolumn{2}{|c|}{$\operatorname{Brix}\left(\mathrm{B}^{\circ}, \%\right)$} \\
\hline & $\begin{array}{l}\text { WDPF } \\
\text { (A) }\end{array}$ & $\begin{array}{c}\text { PDPF } \\
\text { (B) }\end{array}$ & $\begin{array}{c}\text { WDPF } \\
\text { (A) }\end{array}$ & $\begin{array}{c}\text { PDPF } \\
\text { (B) }\end{array}$ & $\begin{array}{c}\text { WDPF } \\
\text { (A) }\end{array}$ & $\begin{array}{c}\text { PDPF } \\
\text { (B) }\end{array}$ \\
\hline Kwangpyongok & $20.4 b$ & $14.1 \mathrm{a}$ & $2 \mathrm{a}$ & $2 \mathrm{a}$ & $9.4 \mathrm{a}$ & $11.0 \mathrm{ab}$ \\
\hline Kangdaok & $24.3 \mathrm{a}$ & $14.2 \mathrm{a}$ & $2 \mathrm{a}$ & $3 a$ & $8.8 \mathrm{ab}$ & $13.5 \mathrm{a}$ \\
\hline P3394 & $19.9 b$ & $13.7 \mathrm{a}$ & $3 a$ & $3 a$ & $8.0 \mathrm{ab}$ & $9.2 b$ \\
\hline P3156 & $21.1 \mathrm{~b}$ & $14.3 \mathrm{a}$ & $3 a$ & $2 \mathrm{a}$ & $8.1 \mathrm{ab}$ & $8.0 \mathrm{~b}$ \\
\hline P32P75 & $21.5 \mathrm{ab}$ & $14.6 \mathrm{a}$ & $3 a$ & $3 a$ & $8.0 \mathrm{ab}$ & $9.3 b$ \\
\hline DK697 & $20.1 b$ & $15.9 \mathrm{a}$ & $2 \mathrm{a}$ & $2 \mathrm{a}$ & $7.0 \mathrm{~b}$ & $9.2 b$ \\
\hline Mean & 21.2 & 14.5 & 2.5 & 2.5 & 8.2 & 10.0 \\
\hline $\mathrm{B} / \mathrm{A}(\%)$ & \multicolumn{2}{|c|}{68.4} & \multicolumn{2}{|c|}{100} & \multicolumn{2}{|c|}{125} \\
\hline
\end{tabular}

WDPF(A) : well drained paddy field, $\operatorname{PDPF}(\mathrm{B})$ : poorly drained paddy field.

* Rating : $1=$ strong(outstanding), 9 = weak(poor).

* Means within a column followed by the same letter are not significantly different at the $5 \%$ level by Duncan's multiple range test. 
로써 이들의 감소는 수량에 직접적인 영향을 주기 때문에 감소폭이 적은 품종을 선택하는 것이 유리하며 수량을 극대화하는 가장 이상적 인 방법은 배수가 잘되는 토양에서 사일리지용 옥수수를 재배하는 것이 안정적인 조사료를 생 산할 수 있고 최대 수량을 올릴 수 있다고 생 각된다.

옥수수의 수량증대에 기여도가 큰 형질인 경 직경은 배수가 불량한 논이 배수가 양호한 논 의 $68.4 \%$ 에 불과하여 수량감소에 많은 영향을 미쳤는데, 배수불량 논에서의 옥수수 경직경은 평균 $6.7 \mathrm{~cm}$ 의 감소를 보였다. 배수 양호한 논 에서 경직경이 가장 굵은 품종은 강다옥으로 $24.3 \mathrm{~cm}$ 였고 배수가 불량한 논에서는 품종간 차이가 없었다.

내습성 정도는 품종간 차이를 보이지 않았으 나 국내품종 중에서는 광평옥이, 도입품종 중
에서는 DK697, P3156 등이 약간 강했다. 또한 사일리지의 품질에 영향을 주는 당도는 배수가 불량한 논에서 강다옥 $13.5 \mathrm{~B}^{\circ}$ 와 배수가 양호한 논에서는 광평옥이 $11.0 \mathrm{~B}^{\circ}$ 로 가장 높았는데 평 균값인 $10.0 \mathrm{~B}^{\circ}$ (배수불량논), $8.2 \mathrm{~B}^{\circ}$ (배수양호논) 보다는 다소 높았다.

\section{2. 사일리지용 옥수수의 생산성}

논 재배 사일리지용 옥수수의 품종별 생초수 량 및 건물수량은 Table 4와 같다. 생초수량은 시험에 공시된 6 품종 중에서 배수가 양호한 포 장에서는 강다옥이 72.3 톤, 도입품종 중에서는 $\mathrm{P} 3156$ 이 68.5톤으로 최고수량을 보였다.

논 조건에 따른 수량변화는 배수가 불량한 논에서는 DK697 품종이 32.6톤으로 다른 품종 에 비해 다소 수량감소가 적었으며, 강다옥으

Table 4. Fresh, dry matter (DM) and total digestible nutrients (TDN) yield of corn hybrids for silage on different drained paddy field conditions

\begin{tabular}{|c|c|c|c|c|c|c|}
\hline \multirow{3}{*}{ Hybrids } & \multicolumn{6}{|c|}{ Yield (kg/ha) } \\
\hline & \multicolumn{2}{|c|}{ Fresh } & \multicolumn{2}{|c|}{ Dry } & \multicolumn{2}{|c|}{ TDN } \\
\hline & $\begin{array}{l}\text { WDPF } \\
\text { (A) }\end{array}$ & $\begin{array}{l}\text { PDPF } \\
\text { (B) }\end{array}$ & $\begin{array}{l}\text { WDPF } \\
\text { (A) }\end{array}$ & $\begin{array}{l}\text { PDPF } \\
\text { (B) }\end{array}$ & $\begin{array}{l}\text { WDPF } \\
\text { (A) }\end{array}$ & $\begin{array}{l}\text { PDPF } \\
\text { (B) }\end{array}$ \\
\hline Kwangpyongok & $64,389 b c$ & $27,670 \mathrm{ab}$ & $19,090 \mathrm{ab}$ & $12,450 \mathrm{ab}$ & $13,200 \mathrm{ab}$ & $8,930 \mathrm{ab}$ \\
\hline Kangdaok & $72,278 \mathrm{a}$ & $21,610 \mathrm{ab}$ & $18,780 \mathrm{ab}$ & $12,690 \mathrm{ab}$ & $12,840 \mathrm{ab}$ & $9,140 \mathrm{ab}$ \\
\hline P3394 & $55,444 d$ & $18,720 b$ & $17,420 b$ & $9,580 \mathrm{~b}$ & $12,390 b$ & $6,810 \mathrm{~b}$ \\
\hline P3156 & $68,500 \mathrm{ab}$ & $23,670 \mathrm{ab}$ & $18,120 \mathrm{ab}$ & $9,830 \mathrm{~b}$ & $12,650 \mathrm{ab}$ & $6,860 \mathrm{~b}$ \\
\hline P32P75 & $68,111 \mathrm{ab}$ & $27,120 \mathrm{ab}$ & $20,400 a$ & $14,910 \mathrm{a}$ & $14,420 \mathrm{a}$ & $10,950 \mathrm{a}$ \\
\hline DK697 & $61,167 \mathrm{~cd}$ & $32,610 \mathrm{a}$ & $18,790 \mathrm{ab}$ & $14,320 \mathrm{a}$ & $13,050 \mathrm{ab}$ & $10,310 \mathrm{a}$ \\
\hline Mean & 64,982 & 25,233 & 18,767 & 12,296 & 13,092 & 8,833 \\
\hline B/A(\%) & \multicolumn{2}{|c|}{38.8} & \multicolumn{2}{|c|}{65.5} & \multicolumn{2}{|c|}{67.5} \\
\hline
\end{tabular}

WDPF(A) : well drained paddy field, PDPF (B) : poorly drained paddy field.

* Means within a column followed by the same letter are not significantly different at the $5 \%$ level by Duncan's multiple range test. 
로 무려 51톤의 감소를 보여 배수조건에 따라 수량의 감소가 가장 큰 품종이었다. 건물수량 을 살펴보면 $\mathrm{P} 32 \mathrm{P} 75$ 가 배수가 양호한 조건보 다 배수가 불량한 논에서 $73.1 \%$ 감소하였고, $\mathrm{DK} 697$ 은 $76.2 \%$ 감소율을 보여 P32P75의 건물 수량 감소율이 적었으며, 건물수량도 14,910 $\mathrm{kg} / \mathrm{ha}$ 로 이 시험에 공시된 6 품종 중에서 최고 의 수량을 보였는데 이와같은 결과는 김 등 (2005)과 지 등 (2009)이 논 재배 사일리지용 옥수수의 건물수량 수준과 비슷하였다.

한편 배수조건에 따른 건물수량 감소가 가장 큰 품종은 P3156으로 약 9톤의 수량 차이를 보 였다. TDN 수량에서도 역시 P32P75 품종이 각 각의 배수조건에서 최고의 수량을 보였다. 이 상과 같은 결과를 요약하면 배수가 불량한 논 에 사일리지용 옥수수를 재배 하였을 경우에 배수가 양호한 논에서 재배한 경우에 비하여
건물수량이 $65.6 \%$ 에 불과하다는 사실을 알 수 있었다. 특히 생초수량에서는 배수가 불량한 논의 수량감소가 커서 배수가 양호한 논재배의 $38.8 \%$ 수준이었다.

\section{3. 사일리지용 옥수수의 품질}

조사료의 품질 특성을 나타내는 조단백질, $\mathrm{ADF}$ 및 $\mathrm{NDF}$ 는 Table 5와 같다. 배수조건에 따른 $\mathrm{ADF}$ 함량은 배수가 불량한 논에서 평균 $6.2 \%$ 의 감소를 보인 반면 $\mathrm{NDF}$ 함량은 오히려 $7 \%$ 증가하였으나 조단백질에서는 배수조건에 따른 차이는 보이지 않았다. 배수가 양호한 논 토양에서 $\mathrm{ADF}$ 함량은 광평옥이 $24.5 \%$ 로 가장 높았고 $\mathrm{P} 3394$ 와 $\mathrm{P} 3156$ 은 각각 $19.6 \%, 19.7 \%$ 로 다소 적었고 배수가 불량한 논에서는 강다옥이 $22.9 \%$ 로 공시품종 중에서 가장 많았다. $\mathrm{NDF}$

Table 5. Acid detergent fiber (ADF), neutral detergent fiber (NDF) and crude protein (CP), of corn hybrids for silage on different drained paddy field conditions

\begin{tabular}{|c|c|c|c|c|c|c|}
\hline \multirow[b]{2}{*}{ Hybrids } & \multicolumn{2}{|c|}{$\mathrm{ADF}(\%)$} & \multicolumn{2}{|c|}{ NDF (\%) } & \multicolumn{2}{|c|}{$\mathrm{CP}(\%)$} \\
\hline & $\begin{array}{l}\text { WDPF } \\
(\mathrm{A})^{*}\end{array}$ & $\begin{array}{c}\text { PDPF } \\
\text { (B) }\end{array}$ & $\begin{array}{l}\text { WDPF } \\
\text { (A) }\end{array}$ & $\begin{array}{c}\text { PDPF } \\
\text { (B) }\end{array}$ & $\begin{array}{l}\text { WDPF } \\
\text { (A) }\end{array}$ & $\begin{array}{c}\text { PDPF } \\
\text { (B) }\end{array}$ \\
\hline Kwangpyongok & $24.5 \mathrm{a}$ & $21.0 \mathrm{ab}$ & $45.8 \mathrm{a}$ & $40.3 b$ & $4.4 b$ & $5.1 \mathrm{a}$ \\
\hline Kangdaok & $22.5 \mathrm{ab}$ & $22.9 \mathrm{a}$ & $43.2 \mathrm{ab}$ & $43.6 \mathrm{a}$ & $5.3 \mathrm{a}$ & $5.1 \mathrm{a}$ \\
\hline P3394 & $19.6 \mathrm{c}$ & $17.8 b$ & $42.1 b$ & $36.6 \mathrm{c}$ & $5.6 \mathrm{a}$ & $5.0 \mathrm{a}$ \\
\hline P3156 & $19.7 \mathrm{c}$ & $18.1 b$ & $42.6 \mathrm{ab}$ & $36.4 \mathrm{c}$ & $5.4 \mathrm{a}$ & $5.8 \mathrm{a}$ \\
\hline P32P75 & $20.4 b c$ & $18.8 b$ & $42.6 \mathrm{ab}$ & $37.0 \mathrm{c}$ & $5.4 \mathrm{a}$ & $5.6 \mathrm{a}$ \\
\hline DK697 & $20.2 b c$ & $21.0 \mathrm{ab}$ & $43.8 \mathrm{ab}$ & $40.0 \mathrm{~b}$ & $5.4 \mathrm{a}$ & $4.9 \mathrm{a}$ \\
\hline Mean & 21.2 & 19.9 & 36.3 & 39.0 & 5.3 & $5.3 \mathrm{a}$ \\
\hline $\mathrm{B} / \mathrm{A}(\%)$ & \multicolumn{2}{|c|}{93.8} & \multicolumn{2}{|c|}{107} & \multicolumn{2}{|c|}{100} \\
\hline
\end{tabular}

* WDPF (A) : well drained paddy field, PDPF (B): poorly drained paddy field.

* Means within a column followed by the same letter are not significantly different at the $5 \%$ level by Duncan's multiple range test. 
함량은 배수가 양호한 논토양에서 광평옥이 $45.8 \%$ 로 가장 높았고 배수가 불량한 논에서는 강다옥이 $43.6 \%$ 로 높은 함량을 보였다. 한편 조단백질 함량은 배수조건에 따라 품종간 차이 는 보이지 않았다.

\section{IV. 요 약}

본 시험은 논에서 배수조건에 따라 벼 대체 여름 사료작물인 옥수수를 논 재배하여 생육특 성과 수량에서 우수한 품종을 선발할 목적으로 2007년부터 2008년까지 2년간에 걸쳐 충남 아 산과 천안 농가 포장에서 수행하였다. 국내육 성 2품종과 도입품종 4품종 등 6품종을 시험한 결과 $\mathrm{P} 32 \mathrm{P} 75, \mathrm{DK} 697$, 광평옥, 강다옥 등이 생 육특성과 수량성에서 우수한 결과를 보였고 배 수조건에 따라 수량은 차이가 큰 것으로 나타 났다. 배수가 불량한 논에서는 옥수수를 재배 할때에는 국산품종으로 강다옥과 광평옥 품종 의 건물수량이 각각 12.7 톤, 12.5 톤/ha 높았고 도입품종으로는 $\mathrm{P} 32 \mathrm{P} 75$ 와 DK697이 14.9톤, 14.3 톤/ha 등으로 다소 유리한 것으로 나타났 다. 또한 사료가치는 $\mathrm{ADF}, \mathrm{NDF}, \mathrm{CP}$ 등에서 약 간의 차이를 보였는데 $\mathrm{ADF}$ 는 배수가 불량 논 에서 다소 감소하였으나 강다옥이 약간 높은 것으로 나타났다. 조단백질은 배수조건에 따라 공시 품종간에 차이를 보이지 않았다. 따라서 본 연구결과를 토대로 볼 때 사일리지용 옥수 수를 논에 재배하기 위해서는 배수가 양호한 논 포장을 선정하는 것이 최우선 조건임을 보 여주고 있다.

\section{V. 인 용 문 헌}

1. 김동암, 조무환, 권찬호, 한건준, 김종관. 1992. 도입 사일리지용 옥수수의 생육특성 및 생산성 비교. I. 지역별 생육특성 및 생산성. 한초지.
12(3):161-172.

2. 김동암, 고서봉, 권찬호, 김문철, 한건준, 김종 덕, 이광녕, 신동은, 김종근. 1997. 중북부 및 제 주지역에 적합한 사일리지용 옥수수의 우량품종 평가. 한초지. 17(4): 323-328.

3. 김종근, 정의수, 서성, 강우성, 양종성, 조영무. 1998. 재식밀도가 사일리지용 옥수수의 수량 및 사료가치에 미치는 영향. 한초지. 18(1):49-54.

4. 김종덕, 김동암, 박형수, 김수곤. 1999. 파종시기 및 품종이 사일리지용 옥수수의 수량과 사료가 치에 미치는 영향. I. 옥수수의 생육특성 및 사 초수량. 한초지. 19(3):211-220.

5. 농촌진흥청. 2006. 작물별 시비처방기준(개정판)

6. 박근제, 김원호. 2002. 벼 대체 논 사료작물 재배 및 이용기술. 농촌진흥청 축산연구소. pp. 39-91.

7. 이호진, 김수형, 이홍석. 1994. 토성 및 지하수위 에 따른 사료용 옥수수와 수수-수단그라스 잡종 의 생육. 한작지. 39(6):585-593.

8. 이석순, 김태주, 배동호, 함태수. 1986. 남부지방 에서 국내육성 및 도입옥수수 품종의 사일리지 생산성. 한작지. 31(2):156-161.

9. 지희정, 김충수, 홍범용, 이희봉. 2006. 논 토양조 건에 따른 찰옥수수 교잡종의 작물학적 특성. 충 남대 농업과학연구. 33(2):123-127.

10. 지희정, 이종경, 김기용, 윤세형, 임영철, 권오도, 이희봉. 2009. 남부지방 논에서 사일리지용 옥수 수 품종의 생육특성, 생산성 및 품질비교. 초지 조사료지. 29(1):13-18.

11. 최기준, 임영철, 김기용, 성병렬, 김맹중, 김원호, 지희정, 이종경, 전병수, 정민웅, 이상훈, 서 성. 2008. 사료용 옥수수의 검은줄오갈병 전국 발생 실태. 초지조사료지. 28(3):221-228.

12. Aldrich, S. R., W. O. Scott and R. G. Hoeft. 1986. Modern corn production A\&L. Publications Inc. Station. Illinois.

13. AOAC. 1990. Official methods of analysis(15th ed.). Association \& Official Analytical Chemists, Washington DC.

14. Goring, H.K. and P.J. Van Soest. 1970. Forage fiber analysis. Ag. Handbook. No. 379. ARS. 
Ji et al.: Forage Production and Quality of Silage Corn on Different Drained Conditions

USDA. Washington DC.

15. Holland, C., W. Kezar, W.P. Kautz, E.J. (접수일: 2009년 10월 13일, 수정일 1차: 2009년 10 Lazowski, W.C. Mahanna and R. Reinhart. 1990. The Pioneer forage manual; A nutritional guide.
Pioneer Hi-Bred., Des Moines, IA.

월 23일, 수정일 2차: 2009년 11월 5일, 게재확정일: 2009년 11월 13일) 